\title{
Continuity and Change in British Anthropology, 1914-1919
}

\author{
HeNRIKa KuKLICK
}

In large part, the activities that British anthropologists undertook during World War I and the conclusions they reached then sustained disciplinary trends that had begun at the turn of the century. The journals produced by the Royal Anthropological Institute (RAI) of Great Britain and Ireland (the geographical terms together equaled the United Kingdom) published very little with direct relevance to the war, and had content practically indistinguishable from prewar or postwar publications; the articles I cite in this chapter constitute the sum total of war-related contributions to RAI journals. ${ }^{1}$ In the meetings of Section $\mathrm{H}$, the anthropological section of the British Association for the Advancement of Science (BAAS), the war may have received somewhat more attention than was expressed in RAI publications, but the societies were not discrete entities - and papers delivered to the BAAS often became printed articles in RAI periodicals. Regardless, there were limited wartime opportunities for BAAS deliberations, since its 1917 and 1918 meetings were cancelled. ${ }^{2}$

1 These journals were Man, published from 1901-1994, which was the vehicle for publication of the "Miscellanea and Reviews" that had previously been a section of the Society's main journal, The Journal of the Royal Anthropological Institute of Great Britain and Ireland (usually referenced as the Journal of the Royal Anthropological Institute, first published in 1872 and titled the Journal of the Anthropological Institute until 1907), which would incorporate Man-and, for a time, take its name.

2 For example, we know that Arthur Keith delivered an address at the 1916 meeting in which he discussed the possibility that the British population was changing in physical terms, but we have no idea what he said, since his paper, like many delivered at the Association's meetings, was not printed; only presidential addresses were invariably published. See Report of the 86th Meeting of the British Association for the Advancement of Science, 1916 (London: John Murray, 1916), 468. 
Consider, for example, the physician-turned-ethnologist C. G. Seligman's 1916 presidential address to Section H. It began by bemoaning "the heavy losses which the Teutonic lust of power has inflicted upon our science, no less than any other department of humane and beneficent activity," and named six persons important in anthropological circles who had died in the war. But thereafter it turned to exposition of the early history of the Anglo-Egyptian Sudan. Similarly, though the physical anthropologist Arthur Keith began his 1917 presidential address at an RAI meeting by saying that in the recent past "our best endeavours, and our best thoughts, have been concerned with the affairs of a great and terrible war," he then told the history of the development of anthropology in Britain as an inspirational tale, which would motivate his listeners to resume their anthropological inquiries after the war's end. Although Keith was among the anthropologists who offered advice to the government during the war, and expressed some frustration that his like-minded colleagues' learned expertise was insufficiently recognized, he also suggested that those contributions which anthropologists made to the war effort did not serve disciplinary ends. ${ }^{3}$ Last, but hardly least, in his 1920 presidential address to Section H, the biometrician Karl Pearson, to whom anthropology was a justifiable enterprise largely because it had practical uses, effectively denounced practitioners of the discipline because their wartime service had no relation to their specialized expertise, notwithstanding their involvement in war-related activities. $^{4}$

Thus, perhaps the most significant feature of organized anthropology during the war was how little notice practitioners seemed to take of it in their scholarly capacities. Nevertheless, wartime experience provided significant confirmation of generalizations that had originated in nonmilitary contexts, and new evidence conduced to redesign of the discipline. In this chapter, I will discuss three major issues that anthropologists addressed during the war. First: What were the physical characteristics of British soldiers? What bearing did assessments of soldiers' characteristics have on questions about the present and future of the British race? Second: Was there some sort of racial basis for the military conflict? Third: How should anthropology's understanding of the basic characteristics of humankind be affected by observations of the behavior of men who suffered mental breakdown on the battlefield? Within the general category of mental distress, called "war neurosis," was an extreme condi-

3 Arthur Keith, "Presidential Address: How Can the Institute Best Serve the Needs of Anthropology?" Journal of the Royal Anthropological Institute 47 (1917): 12.

4 Karl Pearson, "Presidential Address," Report of the 88th Meeting of the British Association for the Advancement of Science, 1920 (London: John Murray, 1920), 36-151. 
tion named "shell-shock" by Charles S. Myers, whose early career spanned the boundary between anthropology and psychology. Myers restricted himself to psychology after the war, probably not least in consequence of his service during the war, which included serving as a consulting psychologist to the British army in France.

\section{The First Issue: The Condition of the British Race}

Late nineteenth-century British anthropologists, like their counterparts in other countries, were concerned about the possibility that the physical stock of their nation was degenerating in quality. In 1883, for example, anthropologists serving on a BAAS Anthropometric Committee warned that the human species would grow extinct if the position of women continued to improve. Recall that this was a period in which Lamarckian ideas were still widespread among scientists. (Indeed, there were trace elements of Lamarckism in Charles Darwin's work, which has long been understood as a definitive repudiation of it.) Lamarckian notions informed the Anthropometric Committee's judgment that inheritance of the qualities that women acquired through education was making successive generations' pelvises increasingly inadequate for delivering babies; making matters worse, babies gestated under civilized conditions had increasingly larger heads. Little more than a decade after the Committee rendered this judgment, wartime experiences made the question of racial degeneration especially urgent.

That is, during the South African War of 1899-1901 (also known as the Boer War), 40 percent of those who presented themselves as candidates for military service were rejected on health grounds-and the British forces in South Africa were hard-pressed to defeat their Afrikaner opponents in the territory that would become the Union of South Africa. After the Boer War, the government convened the Inter-Departmental Committee on Physical Deterioration to consider the physical condition of the British race, and the Committee called persons who were prominent in anthropological circles to testify as expert witnesses. Of great significance to the Committee were the opinions of the professor of anatomy at the University of Edinburgh, D. J. Cunningham, whose anthropological activities had included joint ventures with the biologist-turned-ethnologist A. C. Haddon (of whom much more in time). Cunningham asserted that what appeared to be signs of decline of the race in terms of its collective hereditary potential were merely transient, circumstantial phenomena-functions of deficient diets, housing, and exercise; Britons' physical defects did not prove, say, that the best of the nation's specimens were failing to reproduce in substantial numbers while the population 
of the lower orders exploded. Indeed, he was especially concerned to deny that the changing role of women was harmful to the race, arguing that enlarged opportunities for women improved their health, freeing them from restrictive corsets and encouraging them to exercise. Cunningham's views were incorporated in the Committee's 1904 Report, which recommended implementation of social welfare measures. ${ }^{5}$

Anthropologists' efforts during World War I were directly inspired by the 1904 report. Anthropologists figured in the Conjoint Board of Scientific Societies, established, in 1916, a private, nonprofit body dedicated to offering advice to the government and the public. The Board's Subcommittee on Anthropology counted among its members such notables as Arthur Keith, Karl Pearson, and the anatomist/paleoanthropologist Grafton Elliot Smith. The subcommittee recommended that all military recruits be examined by the newly established Medical Boards. ${ }^{6}$ Information accumulated during World

5 For a lengthy analysis of the debates about the status of the British race, the Boer War, and the Inter-Departmental Committee, see Henrika Kuklick, The Savage Within (New York: Cambridge University Press, 1991), esp. 133, 152153, 172.

6 Arthur Keith, "Anthropological Activities in Connection with the War in England," American Journal of Physical Anthropology 1 (1918): 91-96. In the journal, it is noted that the article was based on information Keith supplied, rather than written by him. Keith's discussion of the measurement of military recruits was evidently intended to inspire a postwar anthropometric survey of the British Isles-which was not realized; see also idem, "Presidential Address," 27. See also Keith's note on French anthropological leaders' active concern to influence military decisions, describing "Une Application Anthropologique à I'Art Militaire," written before World War I by the secretary of the Anthropological Society of Paris, which had "passed without notice in this country"; idem, Report of the 85th Meeting of the British Association for the Advancement of Science, 1915 (London: John Murray, 1916), 671. While in pedagogic and professional contexts the differentiation of British anthropology's subspecialties-physical anthropology, social anthropology, and archaeology - was not effected until the end of the interwar period (and never effected in the publications of the RAI), it was beginning at this time. The nonevent of the anthropometric survey is one indicator of the changes that were taking place in the discipline and, in particular, of the decline in prestige of physical anthropology. Social anthropology became the largest and most prestigious of the discipline's subfields, not least because it was advertised as useful to colonial administrators. (That professional social anthropologists were usually disdained by colonial governments, and their largest source of financial support was the American Rockefeller Foundation, is another matter. Anthropological developments during the interwar period are discussed at various subsequent points in this chapter.) Pearson, "Presidential Address," 36-151. 
War I corroborated the 1904 Committee's conclusions. That is, during the course of their military training, British soldiers showed dramatic personal improvement in every particular, and especially in their physical conditions, owing to their existence in "ideal open-air conditions, and ample and excellent food." Here was compelling evidence that the state of the British race was considerably affected by environmental factors.

Nevertheless, there was fear that military casualties could remove the finest specimens of British manhood from the breeding stock of the next generation-a fear that was often expressed. ${ }^{8}$ But it was countered by two different arguments. One was that soldiers fighting in battlefields relatively close to Britain were given leaves of sufficient length to permit them to visit their wives at home and procreate, even though they might be killed after they returned to battle. The other was that soldiers who became casualties were the least fit of the fighting forces; those best suited to reproduce would survive and return to civilian life. Indeed, to some, the most disturbing prospect was that the best specimens of British womanhood would withdraw from the breeding pool because of the war. As men left the British workforce to fight, women gained unprecedented opportunities to make occupational advances. Perhaps the most successful of unmarried self-supporting women might decide to remain unmarried, or would defer marrying until they could do so under particularly attractive terms; thus, the best suited might reproduce in smaller numbers than they could have done had they married at younger ages. ${ }^{9}$

What were the implications of wartime findings for postwar efforts to improve the quality of the population? In short, what policies might be adopted in the name of eugenics, the project conceived and named by Charles Darwin's cousin and anthropological luminary Francis Galton? Consider the research of Pearson, who, in 1911, became the first occupant of the chair in eugenics established with funds bequeathed by Galton at University College, London. Pearson is best remembered for his position that biological laws governed not only the intergenerational transmission of physical characteristics, but also such traits as temperament and aptitude, and that heredity was far more important in determining individuals' characteristics than environmental factors. He took this position in 1903, when he delivered the address in memory of Thomas Huxley that was an annual event of the RAI, then the Anthropological Institute. (The Institute was given a Royal charter in 1907, which may be taken as an index to the respect that the discipline had then earned as a truly scientific enterprise.) The Inter-Departmental Committee on Physical Deterioration

7 Sir Hercules Read, "Presidential Address: Anthropology and War," Journal of the Royal Anthropological Institute 49 (1919): 14.

8 For one illustration, see Pearson, "Presidential Address," 144.

9 Ibid., 17-19. 
was considering Pearson's ideas at the time of his Huxley lecture, speculating that the British population as a whole was deteriorating because its inferior specimens were reproducing out of proportion to their numbers, but, as I have already observed, made no recommendations suggested by his ideas.

Just as significant, Pearson and members of his professional circle did not restrict their research to documenting laws of inheritance. For purposes of suggesting possible policy interventions, they investigated the importance of environmental factors in individuals' growth-factors that were more amenable to deliberate intervention than biological relationships. Pearson and his colleagues undertook a congeries of studies, including his own On the Relationship of Health to the Psychical and Physical Characters in School Children, published in 1923. Indeed, no environmental factor was too trivial to investigate. Consider the work Pearson produced in collaboration with Mary Noel Kan, Study of the Data Provided by a Baby-Clinic in a Large Manufacturing Town, published in $1922 .{ }^{10}$ Controlling for variation that might be a function of class, this study found that babies were healthiest if dressed in wool garments, slightly less healthy if dressed in cotton, and least healthy if clothed in cotton-wool mixtures. Although Pearson never abandoned the position that nature was far more important than nurture in determining individuals' characteristics, it is notable that he devoted considerable time to research into the effects on individuals' life chances that environmental changes might make. Britain may have been the birthplace of the eugenics movement, but its response to the fears that provoked this was movement toward the development of a welfare state. It enacted little legislation that constituted either "positive" or "negative" eugenics - that is, respectively, measures designed to encourage the putatively inherently superior members of its population to have more children, as opposed to actions that eliminated the supposedly unfit from the breeding population through involuntary sterilization or outright murder. In notable contrast, the United States passed eugenics legislation, with the state of California leading the nation in enthusiasm and practice; American laws sanctioned involuntary sterilization as the application of scientific knowledge to policy making-and served the National Socialists who implemented the "final solution" as an example that justified their more radical eugenics program. ${ }^{11}$

10 See Henrika Kuklick, "The British Tradition," in A New History of Anthropology, ed. idem (Oxford: Blackwell, 2008), 59.

11 The definitive work on the eugenics movement, which makes the distinction between "positive" eugenics (broadly defined, this category includes public health measures) and "negative" eugenics is Daniel J. Kevles, In the Name of Eugenics: Genetics and the Uses of Human Heredity (New York: Knopf, 1985). 


\section{The Second Issue: Was There a Racial Basis for World War I?}

No later than 1903, Myers had asserted that it was a "familiar modern dictum" among anthropologists that there were no "pure" races in existence; within any given population, there was considerable variation in biological (as well as social) traits, although populations might differ both in their degree of variability and in the relative frequency of specific traits among them. ${ }^{12}$ In his 1920 presidential address to Section $\mathrm{H}$, Pearson reiterated this dictum. ${ }^{13}$ Did the war provide an occasion for some British anthropologists to modify their views of race? Andrew Evans has recently argued that the anthropometric studies of prisoners-of-war (POWs) in Germany that physical anthropologists conducted during the war contributed to decisive changes in the development of German anthropology as a discipline. Examining captives of diverse points of origin and focusing on those thought to be quite different from themselves, German anthropologists established correlations between race and nationality and laid some of the foundations for the German scientific racism that developed in the 1920s and 1930s. Moreover, to have studied POWs proved to have been a good career move in postwar German anthropology. ${ }^{14}$ The apparently analogous inquiries of British physical anthropologists were simply surveys of German POWs and led to rather different conclusions.

Significantly, such figures as the now-forgotten F. G. Parsons and the wellremembered, distinguished W. E. Le Gros Clark (who achieved the rank of Captain during the war) reported their findings tentatively after examining POWs in British hands. Above all, they worried about the effect of the socalled "personal equation"-differences in individuals' perceptions-on the measurements they took. Inconsistent judgments of such physical characteristics as head form and facial features were to be expected. Indeed, the war itself presented occasions for revelation of the unreliability of anthropometric evaluations, since initial assessments of the characteristics of individual prisoners, taken when they were captured, differed from the results of subsequent measurements of the same individuals. Furthermore, particular traits defied precise specification, since their classifications were affected both by the situations in which they were studied and by scientists' idiosyncrasies when they

12 Charles S. Myers, "The Future of Anthropometry," Journal of the Anthropological Institute 33 (1903): 37.

13 Pearson, "Presidential Address."

14 They paid virtually no attention to the British POWs, for example. See Andrew D. Evans, "Anthropology at War: Racial Studies of POWs during World War I," in Worldly Provincialism: German Anthropology in the Age of Empire, eds. H. Glenn Penny and Matti Bunzl (Ann Arbor, MI: University of Michigan Press, 2003), 198-229. 
used supposedly fixed typologies. That is, anthropologists doubted that they could make consistent observations of skin and eye color as well as of hair characteristics. There had been efforts to create standard color swatches for classifications of skin and eye color, such as those that were printed in the successive editions of Notes and Queries on Anthropology, jointly produced at irregular intervals by the RAI and the BAAS. But using these swatches was problematic: Comparisons could be affected by whether observations were taken indoors or outdoors and by qualities of light under any circumstances. Classifications of individuals' eye colors varied, depending, say, on whether an anthropometrist attached special significance to the color of the rim of the iris. Consistent measurements of hair color and texture were impossible, depending as they did on such factors as whether any given head of hair had been washed recently and how it was dressed. It was hard to judge a man's height when he was lying down, as wounded POWs often were. Finally, when physical anthropologists were not worrying about how results could be affected either by the personal equation or the conditions under which measurements were taken, they debated the very possibility of standardizing anthropometric techniques. ${ }^{15}$

Regardless, perhaps the most important question that concerned physical anthropologists was whether in fighting the Germans the British were fighting their close relatives. There was a well-established tradition of historical analysis that a significant proportion of the peoples who colonized Ancient England were of German stock. The migrants' habits of "Teutonic liberty" had made "England the purest type of the free Germanic polity," in which individuals' freedom was considerable because local government was exceptionally strong. ${ }^{16}$ Teutonic ideals and institutions spread throughout Great Britain and were perpetuated from generation to generation as well as transmitted to the migrants who came to Britain from time immemorial to the present day. Parsons and Le Gros Clark, like their German counterparts, found racial differences between British and German soldiers, although the ancient colonists of England had been Germanic. Paradoxically, then-contemporary Britons were in racial characteristics closer to the ancient inhabitants of the territory that became Germany than present-day Germans. Measuring such traits as head form, British physical anthropologists concluded that the population of

15 See, for example, F. G. Parsons, "A Reply to Mr. Pyecraft's Plea for a Substitute for the Frankfort Base-Line," Man 16 (1916): 71-73; W. P. Pyecraft, "A Plea for a Substitute for the Frankfort Base-Line: With an Account of a New Method of Drawing Skull Contours," Man 15 (1915): 101-106; A. J. N. Tremearne, "A New Head-Measurer," Man 15 (1915): 87-88; F. G. Parsons, "The Colour Index of the British Isles," Journal of the Royal Anthropological Institute 50 (1920): 159-182. The late nineteenth-century British historian William Stubbs, quoted in Stefan Collini, Donald Winch, and John Burrow, That Noble Science of Politics (Cambridge, UK: Cambridge University Press, 1983), 204. 
Germany had changed considerably over time; through successive waves of migration, persons of Alpine and Slavic stock had constituted increasingly larger proportions of Germany's inhabitants. ${ }^{17}$

Nevertheless, British physical anthropologists did not use their analyses of German POWs to equate the German population with a distinctive race. They plotted racial variation within Germany using an updated version of the so-called "index of nigrescence" developed by John Beddoe to describe racial variation throughout the British Isles. Although improved knowledge and techniques suggested modifications in Beddoe's approach, it was still fundamentally sound-and superior in conceptualization and application to the work of contemporary German physical anthropologists. Beddoe's research indicated a range of racial types distributed throughout Britain. ${ }^{18}$ His analysis was consistent with the dominant view among late nineteenth-century British anthropologists: The population as a whole represented variously blended mixtures of three basic stocks. That is, in such isolated geographical areas as the small islands near the mainlands of Scotland and Ireland, there were populations that had idiosyncratic characteristics. But there were not gross distinctions among the peoples of England, Ireland, Scotland, and Wales that would justify classifying them as separate racial types; in each of these areas, the population was of mixed ancestry. As the BAAS Anthropometric Committee reported, the most marked physical variations among the nation's population were associated with class, not race: The poor, and particularly the urban poor, were notably shorter and thinner. (This finding was consistent with the inquiries into the possibility of racial degeneration that I have already discussed.)

For British anthropologists, then, the absence of a clear association between geography and race meant that there was no justification for the late nineteenth-century argument that the Irish were a qualitatively different race, inherently incapable of the behavior necessary for full citizenship in the United Kingdom. From a contemporary perspective, endorsement of Irish Home Rule seems a liberal political position, but it was a complicated issue when it became controversial-and about which persons of generally liberal inclinations were

17 F. G. Parsons, "Anthropological Observations on German Prisoners of War," Journal of the Royal Anthropological Institute 49 (1919): 20-35. Also see Arthur Keith, "Presidential Address: The Bronze Age Invaders of Britain," Journal of the Royal Anthropological Institute 45 (1915): 12-22. It is worth noting that the subject of human migrations was of considerable interest to late nineteenthand early twentieth-century anthropologists, although the particulars of their narratives varied considerably. That they were interested in migrations is hardly surprising, given that they were living in an era in which there was much population movement.

18 On Beddoe, see, for example, George W. Stocking, Jr., Victorian Anthropology (New York: Free Press, 1987), 66-67. 
sharply divided; it figured prominently in the decline of the Liberal party. (For the Fabian socialists Beatrice and Sidney Webb, for example, Irish Home Rule was essential to separate Great Britain from a people they called "this detestable race." ${ }^{\text {"19 }}$ But late nineteenth-century British anthropologists did not judge the Irish to be a separate, inferior race, and the leading lights of the field were vehemently opposed to Home Rule for Ireland. ${ }^{20}$ By analyzing the German population as a mixture of various stocks, just as the British population was, anthropologists suggested that the German soldiers who fought in World War I were not drawn from a distinctive race that was suited to a way of life utterly alien to British norms.

In sum, British anthropologists of the World War I era did not conflate race, culture, and nation. Early in the war, Elliot Smith argued that there were "legitimate national aspirations" which could only be realized through implementation of "the art of tolerance and the spirit of compromise"; rhetorical appeals to "due recognition of the claims of race and nationality" were predicated on ignoring "a multitude of other factors." ${ }^{21}$ Subsequent history did not provoke dissent from such views. Consider the statement published in the Journal of the Royal Anthropological Institute in 1919 by Harold Peake, a devoted amateur anthropologist (he was independently wealthy):

It is always unwise to use an ethnic term as a designation for a race, and a linguistic term usually serves no better. There is no country whose population is racially uniform, no language which is spoken by one race alone, or by all members of a race. Therefore, we have given up talking of the English race, and have left the term British race to journalists [...]. ${ }^{22}$

This is hardly to say that anthropological arguments linking ethnicity and nation were not invoked when the victors of World War I redrew the map of Europe. Ethic issues figured prominently in the deliberations of the parties to the Paris Peace Conference of 1919. The official participant in the Conference

19 Quoted in Kuklick, The Savage Within, 116. Italics in the original.

20 Ibid., 114-116. It is of parenthetical interest that contemporary geneticists have used DNA testing to confirm nineteenth-century anthropologists' judgment that the populations of all parts of the British Isles were essentially a single people, though they differ considerably in their identifications of the origins of the components of this people. See Nicholas Wade, "A United Kingdom? Maybe," New York Times, March 6, 2007, F1, F4.

21 G. Elliot Smith, "Opening Statement" to a joint session of Section H and Section E (Geography) of the BAAS. Report of the 85th Meeting of the British Association for the Advancement of Science, 1915 (London: John Murray, 1916), 672.

22 Harold Peake, "The Finnic Question and Some Baltic Problems," Journal of the Royal Anthropological Institute 49 (1919): 186. 
who was most committed to the idea that national boundaries should be determined by ethnic affinities was Arthur Balfour, most famous for the 1917 official declaration known by his name, which pronounced that Palestine would become a homeland for the Jewish people. Balfour was hardly naïve, and he consistently promoted the application of scientific knowledge to public policy; he was personally connected to many members of the intellectual aristocracy, not least of these his younger brother Francis, the outstanding physiologist of his generation (and Haddon's original scientific role model). Balfour had been Britain's Prime Minister before the war, and became Foreign Secretary during it. At the Paris Peace Conference itself, he was at the height of his influence during the period when both Britain's Prime Minister, Lloyd George, and America's President, Woodrow Wilson, were absent. He argued effectively for the re-creation of Poland, a nonexistent entity since 1795, its diverse parts having been annexed by Germany, Russia, and the Austro-Hungarian Empire. For Balfour, ethnic characteristics could be ignored only if the national boundaries drawn on strictly ethnic lines entirely would lead to nonviable economic polities. $^{23}$

Was the war followed by major changes in British physical anthropology? No. It remained, as it had been-an enterprise with diverse factions, some more influential than others. Its practitioners had common meeting grounds in such settings as the RAI and the Section H of the BAAS, but their intellectual diversity was a function of their employment in a range of institutional settings, from anatomy departments to agricultural experiment stations. For example, in the World War I era, they debated the merits of Franz Boas's study of the characteristics of the American-born children of immigrants. Some, such as Haddon, writing in 1910, found Boas's findings compelling, because they showed intergenerational variation in head form; to Haddon, Boas's finding was especially significant, because head form had been thought among the most stable of intergenerational characteristics. Recall that head form figured prominently among the variables that physical anthropologists in both Britain and Germany considered in judging what racial variation obtained among the nations that were parties to World War I. At this time, Haddon had enormous influence in organized anthropology, and his opinion carried considerable weight. ${ }^{24}$ But there were other prominent figures in the anthropological com-

23 On Balfour, see, for example, Margaret Macmillan, Paris 1919 (New York: Random House, 2001).

24 A. C. Haddon, "Environment versus Heredity," Nature 2140 (1910): 11-12. Haddon (1855-1940), was at this time Reader in Ethnology at Cambridge University, and retired as such in 1926 (there was no professor of anthropology at Cambridge until 1932). This was not to say that findings about changes in head form could not be interpreted differently. For example, though Pearson had nothing specific to say about Boas's study, he dismissed head- 
munity, such as H. J. Fleure, who differed with him, writing in 1914 that Boas's conclusions were merely indications of flawed methodology. ${ }^{25}$ Along with Fleure, many who were impressed by the recently rediscovered Mendelian laws of heredity argued for the sustained durability of different race types in the British population-while also endorsing the conclusion that the population as a whole was mixed. ${ }^{26}$

If Haddon's approach represented conventional wisdom, it was not accepted by everyone. Moreover, the deliberations of the postwar years did not yield consensus. Perhaps the best illustration of British physical anthropologists' intellectual disarray was their difficulty in reaching collective agreement about how to counter National Socialist scientific racism. A Race and Culture Committee was formed in 1934 under the auspices of the RAI, with the support of the Institute of Sociology. (Interestingly, it included no Jews, since they were deemed insufficiently objective to assess National Socialist propagandaalthough there were Jews active behind the scenes in the Committee.) But the Committee failed in its task; its 1936 report was inconclusive. The race question had to be resolved somehow, however. In 1936, the BAAS zoology and anthropology sections held a joint meeting that addressed the question, concluding that the word "race" should be eliminated from scientific and public discourse, because it had been thoroughly politicized-echoing the argument of We Europeans (1935), coauthored for a popular audience by A. C. Haddon and the biologist Julian Huxley-Thomas Huxley's grandson. ${ }^{27}$ Under such circumstances, the minority of anthropologists who were scientific racists could be overwhelmed. In sum, unlike in Germany, in which wartime experience

form measurements as of no disciplinary value, saying that they, along with all manner of anthropometric measurements, had no correlation whatsoever with hereditary traits; Pearson, "Presidential Address," 186-187.

$25 \mathrm{H}$. J. Fleure, review of Descendants of Immigrants, Changes in Bodily Form of by Franz Boas, Man 14 (1914): 206-208. Fleure (1877-1969) was, in 1914, professor of zoology and lecturer in geography at the University of Wales, Aberystwyth, where he later became professor of geography and anthropology in 1917; he then became professor of geography at Manchester University in 1930, retiring in 1944. Although he held high offices in both the RAI and Section $\mathrm{H}$ throughout his career, the variation in his professional identity over time suggests that his sort of physical anthropology was growing less fashionable after the war.

26 Idem, review of Anthropology and History by William McDougall (Robert Boyle Lecture, Oxford 1920), Man 20 (1920): 190-191; idem and L. Winstanley, "Correspondence on 'Anthropology and Our Older Histories,'" Man 19 (1919): 129-132.

27 See Elazar A. Barkan, The Retreat of Scientific Racism (New York: Cambridge University Press, 1992), 286-296. 
seemed to clarify the relationship between race and nation for anthropologists, in postwar Britain, there was still variation in opinion.

\section{The Third Issue: War Neurosis-Its Origins and Implications}

This is the feature of my narrative with the most significant anthropological pedigree-and which represents the most important legacy that wartime experience left to British anthropology. The reader may initially wonder why this is the case, but the origin point of this narrative was the 1898 Cambridge Anthropological Expedition to Torres Straits, which took a seven-man team to do fieldwork on a cluster of islands located between Australia and New Guinea from late April to mid-November; Myers, who would coin the term shellshock, was one member of the team. The team's organizer was Haddon, who assumed the first position established in ethnology at Cambridge University shortly after the expedition concluded. The expedition's leading intellectual light was W. H. R. Rivers, who was, in 1898, Cambridge's lecturer in experimental psychology and the physiology of the senses (in which capacity he had taught Myers). The overarching conceptual scheme that informed the expedition's inquiries was Darwinian biogeography. ${ }^{28}$ In this chapter, there is no reason to summarize the various ways in which the expedition's findings corroborated this scheme, nor is there need to explain why Rivers would shortly pronounce that fieldwork must be done by individuals, rather than teams, and that adequate research required at least a year spent in the field. What matters is the model of individual action consistent with Darwinian biogeography that Rivers expounded in the expedition's reports. This was his explanation of human action as adaptive behavior.

Rivers addressed the question of the relationship between biological and cultural evolution. It had long been argued that in biological terms so-called primitives were closer to the lower animals than evolved Europeans: Primitives supposedly had acute eyesight and hearing and were relatively insensible to pain. When Rivers employed methods developed in European psychological laboratories to test islanders' sensory responses, he demonstrated that the islanders did not have innately superior sensibilities; indeed, their hearing was not as good as that of members of the expedition team. Of necessity, however, the islanders had cultivated their observational skills in order to survive in unimproved nature. For example, they were highly alert to signs of impeding

28 For a general account of the expedition, see Henrika Kuklick, "Islands in the Pacific: Darwinian Biogeography and British Anthropology," American Ethnologist 23 (1996): 611-638. 
danger as well as able to recognize edible animals looming in the distance. But Europeans placed in circumstances similar to primitives were fully capable of developing equivalent sensory skills. There was the specific issue of the islanders' relative indifference to the color blue: Perhaps it showed that, in at least this instance, they were at a lower level of biological evolution than Europeans-in a state of arrested development-since, like European children, they preferred red. Moreover, the dark pigmentation of the macula in their eyes created a slight insensitivity to blue. Still, psychological tests showed that the islanders could recognize the color. They were not, however, as appreciative of blue as were advanced Europeans-since admiration of the color was an element in the aesthetic contemplation of nature for which they had no time. Indeed, Europeans who had lived among primitive peoples and followed their ways of life provided important anecdotal evidence; their experience indicated that, when Europeans were in positions in which they had to focus on basic survival, they lost interest in the high intellectual activities that had once engaged them.

The general principle that explained cultural variation was the law of the conservation of energy, underpinning an energetic model that informed disciplines from physics to physiological psychology. That is, Rivers understood the human body as a closed energy system: The way that individuals expended their fixed portion of energy determined the quality of their lives. Primitives' lives did not afford opportunities for philosophical speculation or aesthetic appreciation, because they were entirely devoted to sheer survival. The physiological psychological tests Rivers administered in the field confirmed that body economies of energy expenditure and not limited biological evolution explained primitives' habits.

Subsequently, Rivers served as a military psychiatrist during World War I, treating victims of shell-shock and achieving the rank of Captain. His therapeutic approach was not predominant. British psychiatrists used a range of therapeutic techniques (some quite punitive) to deal with victims of shellshock, and, in fact, their practices were similar to those used by psychiatrists in military employment in other forces fighting the war. ${ }^{29}$ What was distinctive about Rivers's approach was that it was informed by his experiences of ethnographic fieldwork. Rivers analogized his patients' behavior to primitives' behavior. Soldiers collapsed on the battlefront, because they could not cope with pressures to act heroically while their lives were constantly threatened. Soldiers were engaged in a literal struggle for existence; indeed, their struggle was far fiercer than that of meeting the requirements of sustaining life in unimproved nature-such as the struggle of the most primitive of peoples. Moreover, no soldier was immune to shell-shock, however heroic he had previously

29 See, for example, Paul Lerner, Hysterical Men (Ithaca, NY: Cornell University Press, 2003), 1-11. 
been in battle, nor did it matter whether his family had a history of mental illness. Any soldier could succumb to shell-shock if his situation became sufficiently threatening. Victims could become infantilized, losing their powers of speech or movement. Soldiers could also lose the capacity for abstract thought. For example, a soldier could become unable to name colors, only capable of seeing that one given object was the same color as another object. As Rivers said, soldiers were "reduced by neural injury to the state of the many peoples who denote colours by their resemblance to natural objects." ${ }^{30}$

Rivers's analysis represented a means to discredit the unilinear evolutionist scheme that had prevailed among nineteenth-century British anthropologists. Its exponents included such luminaries as E. B. Tylor and J. G. Frazer. Tylor, born in 1832, was the most eminent anthropologist of his generation and the occupant of the first university position established in Britain for the subjectthe readership in anthropology created for him in 1884. Frazer, born in 1854, a fellow of Trinity College, Cambridge, was the last notable anthropologist to use the nineteenth-century model. To document the unilinear evolutionist scheme was to demonstrate that all peoples, everywhere, developed along an invariant route of progress from humankind's most primitive condition to its highest form-European civilization; peoples differed in the pace of their evolution, but not the direction it took, the pace being determined by such factors as geographical conditions.

Rivers did not doubt that there were higher and lower forms of behavior. He insisted, however, that each individual had the potential to exhibit the full range of behavioral possibilities. It was also significant that the symptoms of shell-shock belied previous sexual stereotypes. The psychological disturbance designated "hysteria" had previously been assumed peculiar to women, as its very name indicates, but the behavior of soldiers during war demonstrated that men were fully capable of becoming hysterical. Not surprisingly, given his identity as a psychologist, Rivers had challenged the unilinear evolutionary scheme by translating historical processes that shaped societies (however much they depended on the cognitive skills of individuals) into a structure of personality dynamics that allowed any given individual to advance and regress (possibly repeatedly) during the course of a lifetime.

Rivers's theoretical alternative to unilinear evolutionism was diffusionism-a historical, rather than a historicist, model. Anthropological diffusionism came in a variety of forms, including those developed in the Germanspeaking world as well as transported (and translated) into terms that North Americans found congenial before World War I. British diffusionism had some very peculiar features, and Rivers did not expound upon the most improbable

30 For a general discussion of the interpretation of shell-shock made by Rivers and his like-minded associates, see Kuklick, The Savage Within, 171. 
elements of its narrative. He announced his enthusiasm for diffusionism in his 1911 presidential address to Section H. Rivers clearly found the diffusionist approach attractive, because it relied on psychological explanations, and it is notable that British diffusionism was articulated by another medically trained figure who became active in British anthropological circles. This was Grafton Elliot Smith, who, during World War I, served as a psychiatrist in the military hospital where Rivers was also stationed and wrote, along with T. H. Pear, what was considered a definitive study of shell-shock.

The most significant feature of Rivers's conceptualization of personality dynamics, however, was that it had no necessary connection to a historically oriented anthropology. Furthermore, the evidence gathered from treatment of shell-shock victims was exceptionally compelling-more compelling than observations made during the Torres Straits Expedition. That is, the unintended experiments that created shell-shock victims yielded exceptionally persuasive evidence, because they were performed on European bodies-and those bodies were vast in number; persons who never fully recovered from shell-shock formed the largest category of military pensioners in Britain after the war. If Rivers's interpretation of shell-shock was by no means the only one available to the military during World War I, it was the only one that affected the direction of British anthropology. (In the military mind, cowardice was a far more acceptable explanation of shell-shocked soldiers' behavior. $)^{31}$

That is, Rivers's energetic model of the body served two anthropological purposes. It explained how the anthropologist as fieldworker could become a scientific instrument by immersing himself in the lifestyle of the people among whom he was working. It is notable that Bronislaw Malinowski described himself in the terms of a fixed energy system in the diaries he kept during the fieldwork he did in the World War I era. (I am not claiming that Malinowski was familiar with Rivers's wartime psychiatric work; but he read Rivers's programmatic injunctions while in the field and acknowledged Rivers's influence on his methodology.) Rivers's scheme allowed anthropologists to repudiate historical analysis-to argue that only synchronic analysis provided significant explanations of variations in human behavior; the shell-shock victim had a personal history, a medical case history, but this had no necessary relationship to collective historical experience. Moreover, since all human beings were capable of degeneration, there was no relationship between biological and cultural variation. Thus, along with W. H. R. Rivers's student A. R. RadcliffeBrown, Bronislaw Malinowski founded the functionalist school of anthropol-

31 This judgment has recently been restored to public consciousness. In August, 2006, the British Parliament issued a group pardon to 306 British and British Empire soldiers who had been executed for such offenses as cowardice and desertion, despite presenting symptoms of shell-shock. 
ogy, which was purely social anthropology, thoroughly differentiated from the disciplines' other subfields. ${ }^{32}$ Functionalists dominated British anthropology from roughly 1930 to 1970 . Clearly, Rivers's wartime observations enabled him to develop his theoretical scheme to its apogee, and its influence was considerable, albeit in some ways that Rivers could not affect (not least because he died in 1922).

There is a certain irony in the conclusion of my narrative. Malinowski might not have put into practice the research method that Rivers preached had he not been interned in Australia during World War I, because he was a citizen of the Austro-Hungarian Empire and thus classified as an enemy alien. He was then Seligman's protégé at the London School of Economics, and he had come to Australia before the outbreak of the war in order to attend the 1914 meetings of the BAAS, held in Sydney and Melbourne. He was as an internee unable to leave the territory under Australia's jurisdiction until after the war ended. He had intended to do fieldwork in the area, but it might not have been so protracted as it was (although it was not quite as lengthy as he intimated) had he not been in Australia when the war began. Arguably, Malinowski's ascent in British anthropology was the single most important disciplinary phenomenon following the war-but its connection to the war was indirect. ${ }^{33}$

32 Shortly before his death, Rivers lamented the fragmentation of anthropology into discrete subfields. See his "Presidential Address: The Unity of Anthropology," Journal of the Royal Anthropological Institute 52 (1922): 12-25. On the young Malinowski's personal saga, early career, and misrepresentation of his fieldwork experience, see Michael W. Young, Malinowski: Odyssey of an Anthropologist, 1884-1920 (New Haven, CT: Yale University Press, 2004). For Malinowski's ascent in postwar British anthropology, see Kuklick, The Savage Within, esp. 208-214. His eminence depended, in large measure, on his ability to secure financing for his students' field research, which he did with the monies provided by the Rockefeller Foundation. During the negotiations that led to the Foundation's support of British anthropology, eminent British scientists observed that Rivers would be the most creative mind in British anthropology, were he not dead; standard Rockefeller policy was to consult leading figures worldwide in whatever research areas they supported, in order to guarantee that Foundation money would be well spent. Interwar British anthropology might have been rather different had Rivers been alive to assume the professional power that Malinowski secured. 
